\title{
Effect of ethephon and indolebutyric acid on yellow mombin propagation via cutting ${ }^{1}$
}

\author{
Mário Leno Martins Véras ${ }^{2}$, Rejane Maria Nunes Mendonça ${ }^{3}$, \\ Christiane Mendes Cassimiro Ramires ${ }^{4}$, Silvanda de Melo Silva ${ }^{3}$, Walter Esfrain Pereira ${ }^{3}$
}

\section{ABSTRACT}

One of the obstacles in the commercial cultivation of yellow mombin (Spondias mombin L.) is the difficulty in establishing a propagation protocol for the species. This study aimed to assess the effect of treating mother plants with ethephon and applying indolebutyric acid (IBA) to yellow mombin cuttings. A completely randomized design was used, consisting of nine treatments, with ethephon $\left(0 \mathrm{mg} \mathrm{L}^{-1} ; 14.5 \mathrm{mg} \mathrm{L}^{-1} ; 50 \mathrm{mg} \mathrm{L}^{-1} ; 85.5 \mathrm{mg} \mathrm{L}^{-1}\right.$; $\left.100 \mathrm{mg} \mathrm{L}^{-1}\right)$ and IBA $\left(0 \mathrm{mg} \mathrm{L}^{-1} ; 872.35 \mathrm{mg} \mathrm{L}^{-1} ; 3,000 \mathrm{mg} \mathrm{L}^{-1}\right.$; $\left.5,127.65 \mathrm{mg} \mathrm{L}^{-1} ; 6,000 \mathrm{mg} \mathrm{L}^{-1}\right)$ doses, combined according to the central compound box, with four replications. Each experimental unit consisted of 12 cuttings. The highest rooting percentages of yellow mombin cuttings were observed without the application of ethephon $(45.83 \%)$ in the matrix plants and with the use of $3,000 \mathrm{mg} \mathrm{L}^{-1}$ of IBA (31.94\%). For the rooting of yellow mombin cuttings, it is not recommended to use ethephon for treating the matrix plant before the cuttings are removed. The dose of $3,000 \mathrm{mg} \mathrm{L}^{-1}$ of IBA provides the maximum rooting of yellow mombin cuttings, being this dose the most recommended for the propagation via cutting.

KEYWORDS: Spondias mombin L.; rooting; plant growth regulator.

\section{INTRODUCTION}

There is little information on the most appropriate propagation method for Spondias species. However, studies have reported good results for vegetative propagation such as stem cutting, since it produces plants identical to the mother plant, reduces juvenility and ensures homogeneity and vigor in its production. Therefore, stem cutting may be a viable strategy for propagating difficult to propagate species (Tosta et al. 2012), including yellow mombin.

\section{RESUMO}

Efeito de ethephon e ácido indolbutírico na propagação de cajazeira via estaquia

Um dos obstáculos ao cultivo comercial de cajazeira (Spondias mombin L.) é a dificuldade em estabelecer um protocolo de propagação dessa espécie. Objetivou-se avaliar o efeito do tratamento da planta matriz com ethephon e aplicação de ácido indolbutírico (AIB), em estacas de cajazeira. Foi utilizado delineamento inteiramente casualizado, composto por nove tratamentos, com doses de ethephon $\left(0 \mathrm{mg} \mathrm{L}^{-1} ; 14,5 \mathrm{mg} \mathrm{L}^{-1}\right.$; $\left.50 \mathrm{mg} \mathrm{L}^{-1} ; 85,5 \mathrm{mg} \mathrm{L}^{-1} ; 100 \mathrm{mg} \mathrm{L}^{-1}\right)$ e de AIB $\left(0 \mathrm{mg} \mathrm{L}^{-1} ; 872,35 \mathrm{mg} \mathrm{L}^{-1}\right.$; $\left.3.000 \mathrm{mg} \mathrm{L}^{-1} ; 5.127,65 \mathrm{mg} \mathrm{L}^{-1} ; 6.000 \mathrm{mg} \mathrm{L}^{-1}\right)$, combinados de acordo com o composto central de box, com quatro repetições. Cada unidade experimental consistiu de 12 estacas. Os maiores percentuais de enraizamento de estacas de cajazeira foram observados sem a aplicação de ethephon (45.83 \%) nas plantas matrizes e com o uso de $3.000 \mathrm{mg} \mathrm{L}^{-1}$ de AIB (31.94 \%). Para o enraizamento de estacas de cajazeira, não recomenda-se o uso de ethephon para o tratamento de planta matriz antes da retirada das estacas. A dose de $3.000 \mathrm{mg} \mathrm{L}^{-1}$ de AIB proporciona o enraizamento máximo de estacas de cajazeira, sendo essa dose a mais recomendada para a propagação via estaquia.

PALAVRAS-CHAVE: Spondias mombin L.; enraizamento; regulador de crescimento de plantas.

Cutting is one of the most widely used propagation techniques, which involves the removal of parts of the mother plant to produce new plants. It is based on the ability of the cutting tissue to regenerate and, consequently, grow adventitious roots and shoots. Cutting may also be used in the direct production of seedlings or rootstock (Denaxa et al. 2012).

However, some plants, including Spondias, exhibit a low rooting capacity, making it difficult to establish cultivars for a large-scale seedling

1. Manuscript received in Sep./2017 and accepted for publication in Dec./2017 (http://dx.doi.org/10.1590/1983-40632017v4749515).

2. Universidade Federal de Viçosa, Centro de Ciências Agrárias, Departamento de Fitotecnia, Viçosa, MG, Brasil.

E-mail: mario.veras@ufv.br.

3. Universidade Federal da Paraíba, Centro de Ciências Agrárias, Departamento de Fitotecnia e Ciências Ambientais, Areia, PB, Brasil.E-mails: rejaneufpb@yahoo.com.br, silvandasilva@gmail.com, walterufpb@yahoo.com.br.

4. Empresa Estadual de Pesquisa Agropecuária da Paraíba, João Pessoa, PB, Brasil.E-mail: christianecassimiro@hotmail.com. 
production using cutting. This is caused by low endogenous auxin levels, what may be solved by using plant growth regulators such as the indolebutyric acid (IBA) (Ferreira et al. 2009).

Several studies have demonstrated the low rooting percentage of Spondias. Souza \& Lima (2005) used apical branch cuttings and IBA doses, obtaining only $8.3-23.3 \%$ of rooting. In a study with imbu trees, Lima et al. (2002) applied IBA at different times after cutting and recorded a higher rooting percentage $(52.58 \%)$ at 30 days after cutting, with no effect for IBA. Rios et al. (2012) observed a low rooting percentage $(33.33 \%)$ in $20 \mathrm{~cm}$ long imbu cuttings treated with IBA $\left(6,000 \mathrm{mg} \mathrm{L}^{-1}\right)$ and planted in March. Tosta et al. (2012) recorded a rooting rate of $95 \%$ in imbu cuttings treated with $3,000 \mathrm{mg} \mathrm{L}^{-1}$ of IBA.

In order to overcome the low rooting rate of cuttings, some studies have indicated that other factors may be involved in the rooting process, such as the nutritional status of the donor or mother plant, since physiological processes of the plant are related to rhizogenesis regulation (Schwambach et al. 2008, Hartmann et al. 2011). Additionally, the nutritional status of the donor may directly influence the rooting of cuttings through its vegetative vigor and the nutritional status of the collected material (Costa et al. 2015).

Thus, many seedling producers use techniques such as treating the mother plant to increase the rooting percentage of its cuttings. Given its significance in rooting, the most widely used hormone is ethylene. Ethylene is synthesized when auxins are applied, stimulating the root formation and development, thereby increasing the rooting percentage of cuttings (Fachinello et al. 2005).

However, some studies have been unsuccessful. For example, Souza (2007) assessed the yellow mombin and imbu propagation by cutting and air layering with the application of ethephon to the mother plant and found that rooting did not increase in both species. For common guava, Marco et al. (1998) reported that $47.22 \mathrm{mg} \mathrm{L}^{-1}$ of ethephon produced the best rooting percentage for cuttings. In Japanese plums (Prunus salicina Lindl), Dutra et al. (1997) obtained $90 \%$ of rooting for the 'Frontier' cultivar, at an ethephon dose of $100 \mathrm{mg} \mathrm{L}^{-1}$.

In Spondias, particularly yellow mombin, there is a lack of knowledge of treatments in mother plants that can improve the rooting percentage of cuttings. As such, this study aimed to assess the effect of treating the mother plant with ethephon and applying indolebutyric acid to yellow mombin cuttings.

\section{MATERIAL AND METHODS}

The experiment was conducted at the Universidade Federal da Paraíba, in Areia, Paraíba state (PB), Brazil, from July to December 2016.

Woody branches were selected from 17 accessions of yellow mombin plants (Spondias mombin L.) from the germplasm bank of the Empresa Estadual de Pesquisa Agropecuária da Paraíba, in João Pessoa (PB).

The branches were collected from plants in the final phenological stage, a few days before the flower initiation. The mother plants were obtained by grafting and ranged from 10 to 20 years old.

A completely randomized design was used, consisting of nine treatments, predetermined according to the central compound box (CCB), for doses of ethephon $\left(0 \mathrm{mg} \mathrm{L}^{-1} ; 14.5 \mathrm{mg} \mathrm{L}^{-1}\right.$; $\left.50 \mathrm{mg} \mathrm{L}^{-1} ; 85.5 \mathrm{mg} \mathrm{L}^{-1} ; 100 \mathrm{mg} \mathrm{L}^{-1}\right)$ combined with IBA $\left(0 \mathrm{mg} \mathrm{L}^{-1} ; 872.35 \mathrm{mg} \mathrm{L}^{-1} ; 3,000 \mathrm{mg} \mathrm{L}^{-1}\right.$; $\left.5,127.65 \mathrm{mg} \mathrm{L}^{-1} ; 6,000 \mathrm{mg} \mathrm{L}^{-1}\right)$, with four replications and each experimental unit consisting of 12 cuttings (Table 1).

The ethephon treatment was performed using Ethrel $^{\circledR}$, which was sprayed onto the mother plants

Table 1. Levels and doses of ethephon and indolebutyric acid (IBA) used in the experiment, according to the central compound box (Mateus et al. 2001).

\begin{tabular}{lcccccccccc}
\hline & \multicolumn{10}{c}{ Treatments/combinations } \\
\hline & 1 & 2 & 3 & 4 & 5 & 6 & 7 & 8 & 9 \\
\hline Ethephon levels & -1 & +1 & -1 & +1 & $+\alpha$ & $-\alpha$ & 0 & 0 & 0 \\
IBA levels & -1 & -1 & +1 & +1 & 0 & 0 & $+\alpha$ & $-\alpha$ & 0 \\
Ethephon doses (mg L-1) & 14.5 & 85.5 & 14.5 & 85.5 & 100 & 0 & 50 & 50 & 50 \\
IBA doses (mg L-1) & 872.35 & 872.35 & $5,127.65$ & $5,127.65$ & 3,000 & 3,000 & 6,000 & 0 & 3,000 \\
\hline
\end{tabular}

Number of treatments $=2^{\mathrm{k}}+2 \mathrm{~K}+1$, where $\mathrm{K}=$ number of factors; $\mathrm{NT}=2^{2}+2.2+1=9 ; \alpha=\sqrt{2}$. 
at 7 days before the branches were removed. The ethephon doses corresponding to the treatments were diluted according to the commercial recommendation for the product ( $240 \mathrm{~g} \mathrm{~L}^{-1}$ of ethephon), which was used to determine the specific dose for each treatment. The ethephon was diluted inside a backpack sprayer and applied to the top of the plants, at an approximate volume of $4 \mathrm{~L}_{\text {plant }}{ }^{-1}$.

At 7 days after application, branches with 3-4 $\mathrm{mm}$ wide and approximately $30 \mathrm{~cm}$ long were collected and wrapped in damp paper, placed in plastic bags and transported for cutting. Next, they were washed in an air-conditioned setting and cut into $20 \mathrm{~cm}$ long cuttings, straight at the top and with a beveled edge on the bottom.

Following the preparation of the cuttings, a hydroalcoholic solution of IBA was prepared by weighing $872.35 \mathrm{~g}$ of IBA and dissolving it in $50 \mathrm{~mL}$ of $96^{\circ}$ alcohol, in a beaker. Once the IBA had completely dissolved, the volume was completed to $100 \mathrm{~mL}$ with distilled water, obtaining an IBA concentration of $872.35 \mathrm{mg} \mathrm{L}^{-1}$. The same procedure was repeated for the remaining doses used. The flasks containing the solutions were wrapped in aluminum foil to prevent photodegradation. Next, the cuttings were grouped together according to the relevant treatments, and $1.0 \mathrm{~cm}$ of the base was placed in the hormone solution for 5 seconds.

The cuttings were planted in tubes with an internal diameter of $26 \mathrm{~mm}$, external diameter of $33 \mathrm{~mm}$ and volume of $55 \mathrm{~cm}^{3}$, filled with a sand and organic compound substrate $(1: 1 \mathrm{v} / \mathrm{v})$, and placed in a greenhouse under a shade screen, at $50 \%$ of light. They were spray-irrigated for 10 seconds, at 15-minute intervals.

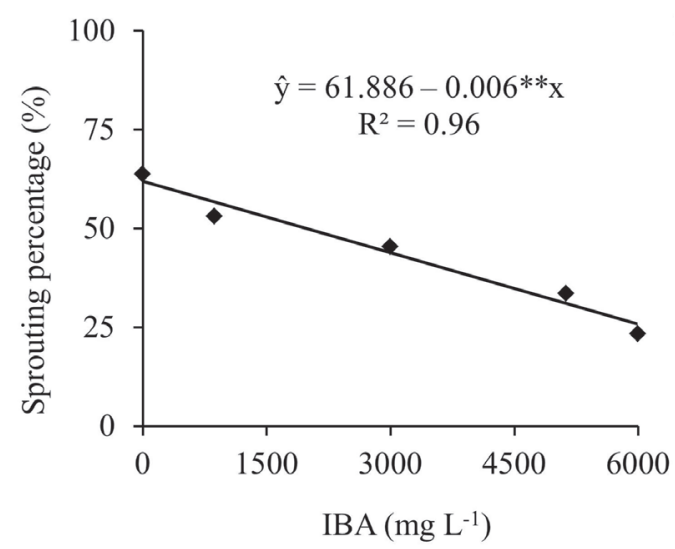

(a)
At 150 days after planting, the cuttings were assessed to determine the sprouting percentage, sprout length, sprout width, number of sprouts per cutting, rooting percentage, percentage of live cuttings with or without calli, percentage of dead cuttings, number of roots per cutting, root length, root, leaf and total dry weight.

The results were submitted to analysis of variance, using the F-test $(\mathrm{p}<0.05)$. The response surface was adjusted for variables with a significant interaction effect; otherwise, polynomial regression was performed. Analyses were conducted using the SAS $^{\circledR}$ statistical software (Cody 2015).

\section{RESULTS AND DISCUSSION}

There was no significant effect for the ethephon x IBA interaction in the variables studied. For the ethephon doses, a significant effect was only observed for number of sprouts, sprout width, rooting percentage, dead cuttings and number of roots. The IBA doses significantly influenced the sprouting percentage, number of sprouts, sprout length and width, rooting percentage, dead cuttings and root length. The remaining variables showed no significant difference for the treatments studied and the data are therefore not presented.

Additionally, a linear model was fit to the IBA doses for the sprouting percentage (Figure 1a) and a quadratic model for the sprout length (Figure 1b), so that the estimated maximum values were recorded without the IBA treatment $\left(0 \mathrm{mg} \mathrm{L}^{-1}\right)$, peaking at $63.75 \%$ (Figure 1a) and $4.49 \mathrm{~cm}$ (Figure 1b), respectively.

This differs from the results obtained by Souza \& Lima (2005) with yellow mombin cuttings,

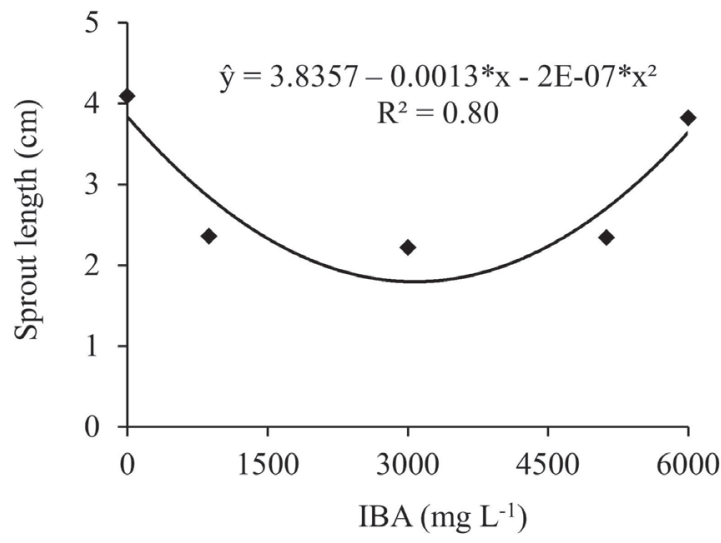

Figure 1. Effect of IBA on the sprouting percentage (a) and sprout length (b), in yellow mombin cuttings. 
where $1,000 \mathrm{mg} \mathrm{L}^{-1}$ of IBA provided the highest sprouting percentage $(73.3 \%)$. Tosta et al. (2012) studied imbu plants and found that IBA affected the sprout length, whereby raising the IBA dose to $3,045 \mathrm{mg} \mathrm{L}^{-1}$ increased the sprout length to $5.6 \mathrm{~cm}$ long. Gomes et al. (2005) also reported that IBA promoted a greater sprout length for imbu cuttings (Spondias sp.).

In the present study, the decline in the sprouting percentage and sprout length in yellow mombin cuttings, as IBA doses increased, may have been due to the cytotoxic effect of high doses of indolebutyric acid. Moreover, there is an inversely proportional correlation between sprout length and rooting, whereby the emergence of sprouts may reduce rooting, because they drain nutrients from the cutting (Fachinello et al. 2005, Peña et al. 2015).

The ethephon doses produced a significant effect in the number of sprouts per cutting (Figure 2a). The regression analysis revealed a decline in this variable up to $50 \mathrm{mg} \mathrm{L}^{-1}$, as ethephon doses rose, followed by an increase up to $100 \mathrm{mg} \mathrm{L}^{-1}$. However, the maximum value was recorded without ethephon. Similarly, IBA doses produced a significant effect in the number of sprouts, whereby an increase in IBA prompted a decline in this variable, reaching a maximum value ( 1.5 sprouts) when the cuttings were submitted to the control treatment, with a minimum of 0.09 at $5,000 \mathrm{mg} \mathrm{L}^{-1}$ of IBA (Figure 2b).

Souza (2007) studied the effect of ethephon concentrations applied to imbu and yellow mombin mother plants and found no significant effect on the number of sprouts on cuttings of these species, obtaining average values of 0.60 and 0.98 sprouts per cutting, respectively.

In imbu cuttings, Tosta et al. (2012) observed an increase in the number of sprouts, as the IBA concentration increased up to $3,500 \mathrm{mg} \mathrm{L}^{-1}$, followed by a decline, with a maximum estimated value of 2.9 sprouts per cutting. Rios et al. (2012) reported no significant effects for the number of sprouts per cutting in imbu cuttings.

This variability in the results of different studies occurs primarily in Spondias, what may be due to the large number of internal and external factors, including endogenous factors such as the nutritional status of the mother plant and exogenous factors such as time of the year when the mother plant was treated and collection time (Fachinello et al. 2005, Rios et al. 2012, Peña et al. 2015).
Sprout width was statistically influenced by the ethephon (Figure 2c) and IBA doses (Figure 2d). A decline was observed in this variable when ethephon was applied to mother plants, with the maximum value $(3.34 \mathrm{~mm})$ recorded for the control treatment (Figure 2c). Similar results were obtained for IBA, when the cuttings were submitted to doses of $0 \mathrm{mg} \mathrm{L}^{-1}$ and $6,000 \mathrm{mg} \mathrm{L}^{-1}$, with values of $2.46 \mathrm{~mm}$ and $2.47 \mathrm{~mm}$, respectively (Figure $2 \mathrm{~d}$ ).

A quadratic behavior was observed in the rooting percentage for the ethephon and IBA treatments applied. The ethephon control treatment (Figure 2e) and IBA dose of 3,000 $\mathrm{mg} \mathrm{L}^{-1}$ (Figure 2f) produced the highest rooting in yellow mombin cuttings, with $45.83 \%$ and $31.94 \%$, respectively. The lowest rooting percentages were recorded at an ethephon dose of $14.5 \mathrm{mg} \mathrm{L}^{-1}$ and without IBA treatment, with values of $11.5 \%$ and $12.5 \%$, respectively.

Prior to rooting, the emergence of new structures on the shoot of the cutting is a drawback, since they act as a drain on carbohydrate reserves and nitrogen compounds, negatively impacting rooting, or even causing the death of the cuttings. By contrast, leaves are important sources of auxins such as indole3-acetic acid (IAA) (Osterc \& Štampar 2011).

The percentage of dead cuttings exhibited a quadratic behavior as a function of the ethephon (Figure $2 \mathrm{~g}$ ) and AIB doses (Figure 2h). This variable increased up to an ethephon dose of $50 \mathrm{mg} \mathrm{L}^{-1}$ and then declined, with a maximum of $53.5 \%$ of dead cuttings at $50 \mathrm{mg} \mathrm{L}^{-1}$ (Figure $2 \mathrm{~g}$ ). The IBA doses reduced the percentage of dead yellow mombin cuttings, with the lowest mortality $(40.6 \%)$ rate recorded at $872.3 \mathrm{mg} \mathrm{L}^{-1}$ (Figure $2 \mathrm{~h}$ ).

Different results were obtained by Gomes et al. (2005), who found no significant effect on imbu rooting for IBA doses. Rios et al. (2012) and Tosta et al. (2012) studied imbu cuttings and recorded the highest rooting percentage at an IBA concentration of $6,000 \mathrm{mg} \mathrm{L}^{-1}$, indicating that the species responds to high plant hormone doses. Paula et al. (2007) assessed rooting in imbu cuttings and reported $33.3 \%$ of rooting with the application of $500 \mathrm{mg} \mathrm{L}^{-1}$ of IBA. With respect to the live cuttings percentage, the same authors found that woody imbu cuttings not treated with IBA exhibited the highest survival percentage (69.4\%).

Among the factors that affect the rooting of cuttings, there may be a strong connection between 


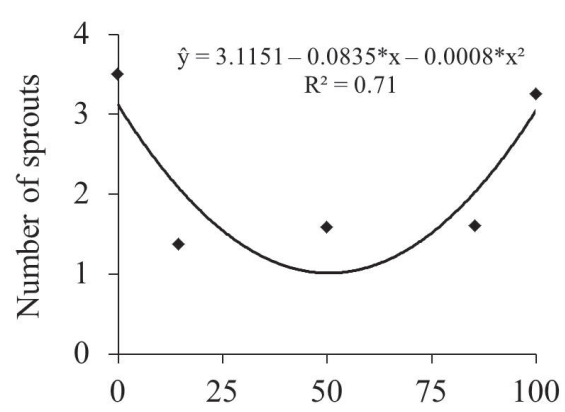

(a)

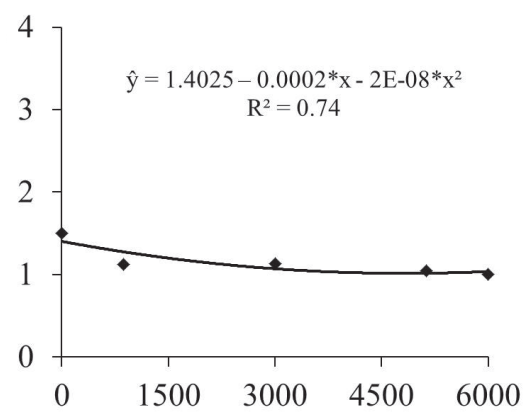

(b)

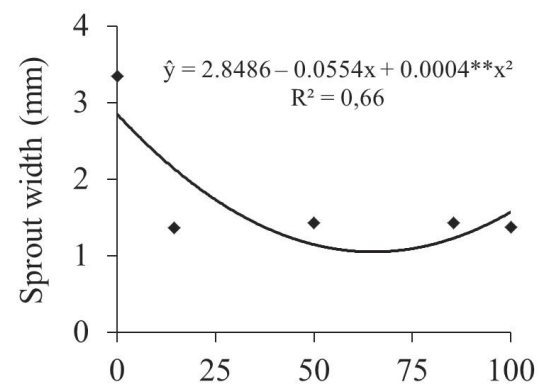

(c)

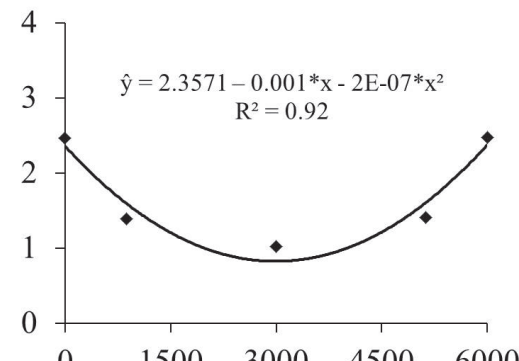

(d)

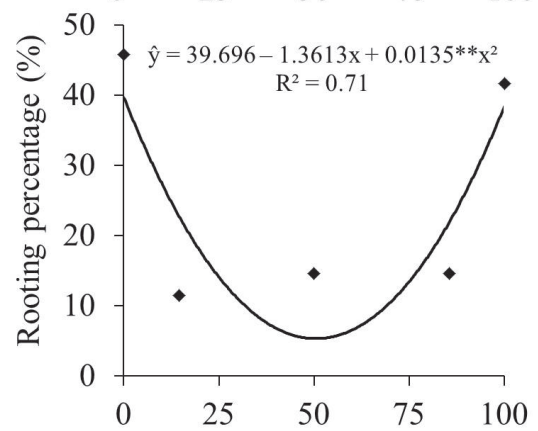

(e)
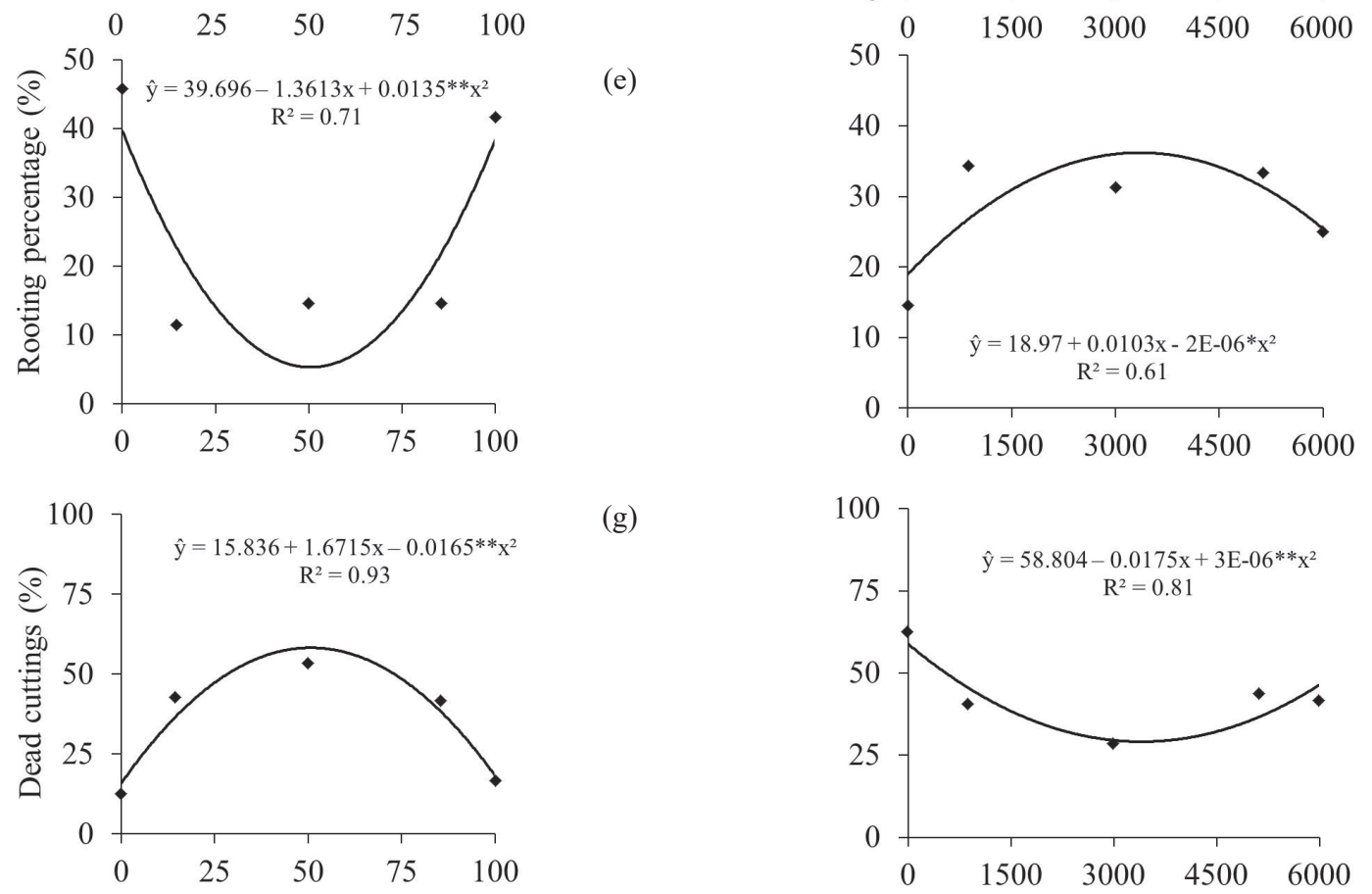

(g)
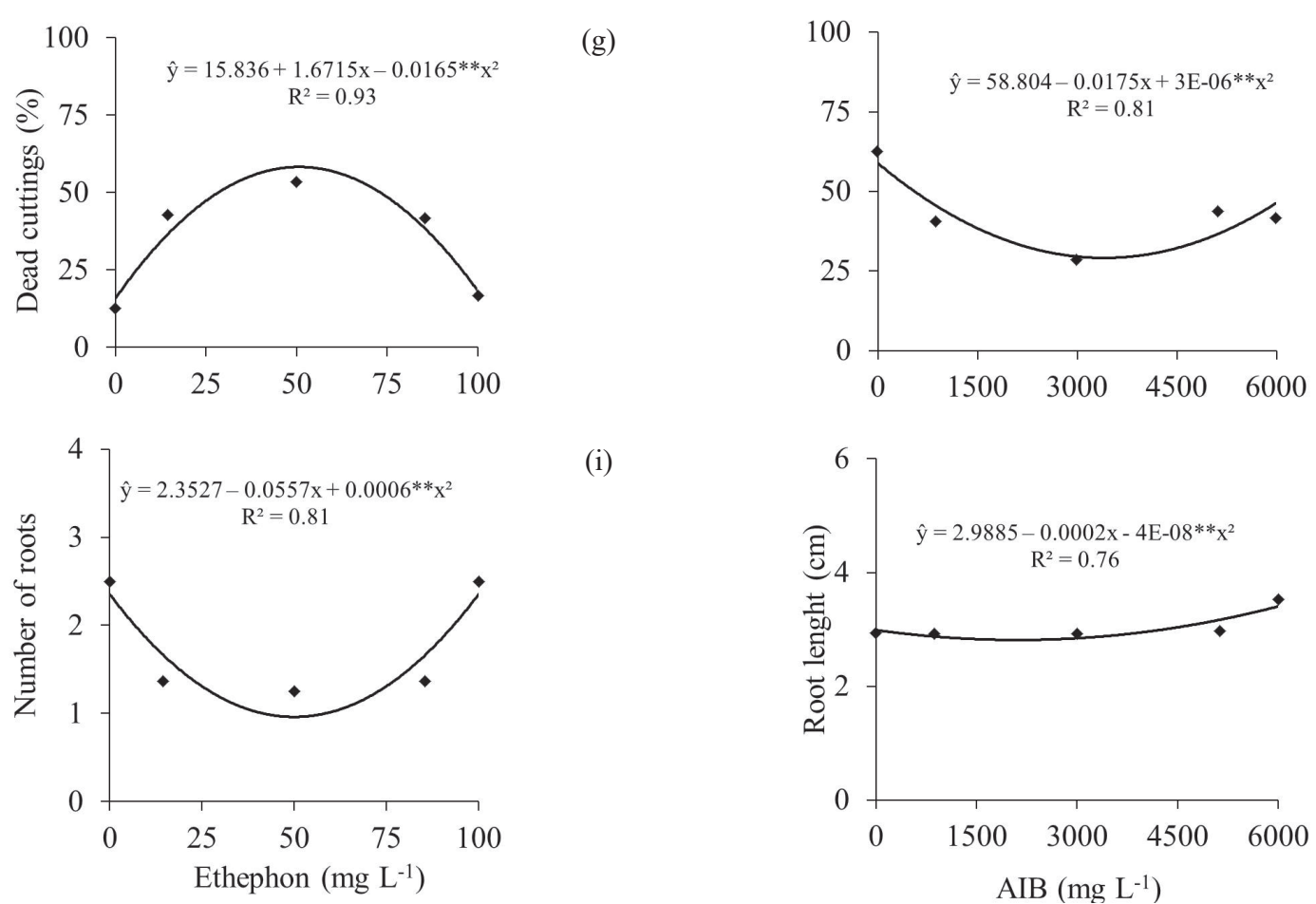

Figure 2. Effect of ethephon and IBA doses on the number of sprouts (a and b), sprout width (c and d), rooting percentage (e and f), dead cuttings ( $g$ and $h)$, number of roots (i) and root length (j) of yellow mombin cuttings. 
callus formation and cutting survival; however, the former varies according to the presence or not of leaves at cutting (Vignolo et al. 2014). Additionally, the environment in which the cuttings are stored directly influences the rooting and mortality percentages, since temperature and humidity may be positive or negative factors (Denaxa et al. 2012, Zang et al. 2013).

The results obtained in the present study may be explained by the beneficial effect of the auxin in some traits, including the sprout development, adventitious rooting, cell elongation, development of meristematic tissue and plant metabolism control. A greater regulation of the genes that adjust the auxin-cytokinin balance may have caused the higher values for rooting percentage observed at an IBA dose of 3,000 $\mathrm{mg} \mathrm{L}^{-1}$. Rooting is greater in cuttings when the auxin level is higher than that of cytokinin, promoting more cell division and, therefore, a greater rooting (Fachinello et al. 2005, Hartmman et al. 2011, Muller \& Leyser 2011, Peña et al. 2015).

The substantial variability in the results obtained at the highest IBA dose, when compared to cuttings not treated with IBA, may be attributed to endogenous and exogenous factors. These include the season in which the plant material was collected, since this affects the nutritional reserves and hormonal balance of plants (Botin \& Carvalho 2015). The hormonal balance influences the callus formation, which is induced from plant tissue samples (explants) in an induction medium (Cheng et al. 2013). In addition to the hormonal balance, the physiological condition of the mother plant, genetic rooting ability, plant or cutting age, type of cutting, collection time, plant health and the possibility of phenolic compound oxidation may affect the rooting of imbu cuttings (Fachinello et al. 2005).

The highest rooting percentage in yellow mombin cuttings at the largest IBA dose may be attributed to the effect of the auxin, raising the level of sugars in the shoot and roots, thus influencing the multiplication and cell elongation and stimulating an adventitious root growth (Fachinello et al. 2011, Hartmman et al. 2011, Muller \& Leyser 2011, Peña et al. 2015).

Some studies indicate that adventitious rooting is characterized by a significant decline in the peroxidase activity, thus increasing the initiation phase and gradually reducing the expression phase. These enzymes may be linked to initial cell division before the organization and growth of root primordia, and act as catalysts in the degradation of IAA, which, in turn, acts as a repressor or inducer of specific peroxidases. As such, the highest rooting percentages observed here for yellow mombin cuttings may be attributed to the larger amounts of IBA applied, which may have reduced the peroxidase activity (Prado et al. 2015).

A quadratic behavior was observed for the number of roots per cutting, as a function of the ethephon doses applied. The ethephon application reduced the number of roots from the control treatment onwards, with a subsequent increase at $100 \mathrm{mg} \mathrm{L}^{-1}$. A similar response was also observed for the control treatment at the maximum dose (100 $\left.\mathrm{mg} \mathrm{L}^{-1}\right)$, both obtaining the same value $(2.5$ roots) (Figure 2i).

A significant effect was recorded for root length, in relation to the treatment with IBA (Figure 2j). An increase in the IBA doses produced longer roots in the yellow mombin cuttings, with $3.53 \mathrm{~cm}$ at the maximum concentration $\left(6,000 \mathrm{mg} \mathrm{L}^{-1}\right)$, reaching a minimum length of $2.23 \mathrm{~cm}$ at $2,500 \mathrm{mg} \mathrm{L}^{-1}$ (Figure 2j).

Tosta et al. (2012) reported a rise in root length (maximum of $5.0 \mathrm{~cm}$ ) up to $1,295.2 \mathrm{mg} \mathrm{L}^{-1}$ of IBA in imbu cuttings, followed by a decline, with a $55.7 \%$ increase for this variable, when compared to the control with no IBA.

This root growth may be explained by the high level of auxins that promote cell division, unlike cytokinins, which induce differentiation. Additionally, the presence of leaves on the cuttings favors rooting, since new leaves in particular participate in the auxin synthesis (Moubayidin et al. 2010).

These positive results for yellow mombin rooting demonstrate the effectiveness of IBA in increasing root volume and length. As such, the treatment with IBA stimulates rooting and enables high-quality cuttings, since a quality root system is essential for the establishment of seedlings in the field and adequate plant development (Silva et al. 2012).

Moreover, a quality root system improves the water and nutrient absorption in the early development stages. A greater root length and a large number of roots are important in the large-scale seedling production, since these parameters are vital to a successful implementation in the field (Carvalho Júnior et al. 2009). 


\section{CONCLUSIONS}

1. The highest percentages for the rooting of the yellow mombin cuttings were observed without the application of ethephon in the mother plant and with the use of $3,000 \mathrm{mg} \mathrm{L}^{-1}$ of IBA;

2. For the rooting of the yellow mombin cuttings, it is not recommended the use of the ethephon treatment in the mother plant before the cuttings are removed;

3. The dose of $3,000 \mathrm{mg} \mathrm{L}^{-1}$ of IBA provides the maximum rooting of yellow mombin cuttings, and this dose is the most recommended for the propagation of this species via cutting.

\section{ACKNOWLEDGMENTS}

To the Coordenação de Aperfeiçoamento de Pessoal de Nível Superior (Capes), for the financial support; Universidade Federal da Paraíba, Campus Areia, for making its facilities available; and Empresa Estadual de Pesquisa Agropecuária da Paraíba de João Pessoa, for the support and for providing the propagation material.

\section{REFERENCES}

BOTIN, A. A.; CARVAlHO, A. Reguladores de crescimento na produção de mudas florestais. Revista de Ciências Agroambientais, v. 13, n. 1, p. 83-96, 2015.

CARVALHO JÚNIOR, W. G. O. et al. Comprimento da estaca no desenvolvimento de mudas de alecrim pimenta. Ciência Rural, v. 39, n. 7, p. 2199-2202, 2009.

CHENG, Z. J. et al. Pattern of auxin and cytokinin responses for shoot meristem induction results from the regulation of cytokinin biosynthesis by auxin response factor. Plant Physiology, v. 161, n. 1, p. 240-251, 2013.

CODY, R. An introduction to SAS. Cary: SAS Institute, 2015.

COSTA, E. M. et al. Enraizamento de estacas de Bougainvillea spectabilis Willd. com o uso de ácido indolbutírico. Acta Agronomica, v. 64, n. 3, p. 221-226, 2015.

DENAXA, N. K. et al. The role of endogenous carbohydrates and seasonal variation in rooting ability of cuttings of an easy and a hard to root olive cultivars (Olea europaea L.). Scientia Horticulturae, v. 143, n. 1, p. 19-28, 2012.

DUTRA, L. F. et al. Enraizamento de estacas de ameixeira (Prunus salicina Lindl) tratadas com ácido indolbutírico e ethephon. Revista Brasileira de Agrociência, v. 3, n. 2, p. 59-64, 1997.

FACHINello, J. C. et al. (Eds.). Propagação de plantas frutiferas. Brasília, DF: Embrapa Informações Tecnológicas, 2005.

FERREIRA, B. G. A. et al. Metodologias de aplicação de AIB no enraizamento de estacas semilenhosas de Sapium glandulatum (Vell.) Pax. Revista Brasileira de Plantas Medicinais, v. 11, n. 2, p. 196-201, 2009.

GOMES, W. A. et al. Enraizamento de estacas de umbucajazeira (Spondias spp.). Procedings of the Interamerican Society for Tropical Horticulture, v. 47, n. 1, p. 231-233, 2005.

HARTMANN, H. T. et al. Plant propagation: principles and practices. 8. ed. São Paulo: Prentice-Hall, 2011.

LIMA, A. K. C. et al. Propagação de umbu-cajazeira (Spondias sp.) e ciriguela (Spondias purpurea) por meio de estacas verdes enfolhadas, nas condições climáticas de Mossoró - RN. Caatinga, v. 15, n. 1, p. 33-38, 2002.

MARCO, C. A. et al. Influence of ethephon and indole butyric on the rooting of stem cuttings of guava (Psidium guajava L.). Ciência Rural, v. 28, n. 2, p. 221-224, 1998.

MATEUS, N. B. et al. Viabilidade de uso do delineamento composto central. Acta Scientiarum Technology, v. 23, n. 6, p. 1537-1546, 2001.

MOUBAYIDIN, L. et al. The rate of cell differentiation controls the arabidopsis root meristem growth phase. Current Biology, v. 20, n. 12, p. 1138-1143, 2010.

MULLER, D.; LEYSER, O. Auxin, cytokinin and the control of shoot branching. Annals of Botany, v. 107, n. 7 , p. 1203-1212, 2011.

OSTERC, G.; ŠTAMPAR, F. Differences in endo/ exogenous auxin profile in cuttings of different physiological ages. Journal of Plant Physiology, v. 168, n. 17, p. 2088-2092, 2011.

PAULA, L. A. et al. Efeito do ácido indolbutírico e raizon no enraizamento de estacas herbáceas e lenhosas de umbuzeiro. Acta Scientiarum Agronomy, v. 29, n. 3, p. 411-414, 2007.

PEÑA, M. L. et al. Miniestaquia a partir de minicepas originadas por enxertia de pitangueira adulta. Comunicata Scientiae, v. 6, n. 3, p. 297-306, 2015.

PRADO, D. Z. et al. Quercetin and indole 3-butyric acid (IBA) as rooting inducers in 'Eucalyptus grandis E. urophylla'. Australian Journal of Crop Science, v. 9, n. 11, p. 1057-1063, 2015.

RIOS, S. E. M. C. et al. Doses de ácido indolbutírico: comprimento e época de coleta de estacas na propagação de umbuzeiro. Revista Caatinga, v. 25, n. 1, p. 52-57, 2012. 
SCHWAMBACH, J. et al. Adventitious rooting of Eucalyptus globulus x maidennii mini-cuttings derived from ministumps grown in sand bed and intermittent flooding trays: a comparative study. New Forests, v. 36, n. 3, p. 261-271, 2008.

SILVA, R. C. et al. Enraizamento de estacas de Melaleuca alternifolia submetidas a diferentes reguladores vegetais. Semina: Ciências Agrárias, v. 33, n. 5, p. 16431652, 2012.

SOUZA, E. P. Propagação da cajazeira e do umbuzeiro por meio de estaquia, alporquia e enxertia. Dissertação (Mestrado em Agronomia) - Universidade Federal da Paraíba, Areia, 2007.

SOUZA, F. X.; LIMA, R. N. Enraizamento de estacas de diferentes matrizes de cajazeira tratadas com ácido indolbutírico. Revista Ciência Agronômica, v. 36, n. 2, p. 189-194, 2005.

TOSTA, M. S. et al. Ácido indolbutírico na propagação vegetativa de umbu-cajazeira (Spondias sp.). Semina: Ciências Agrárias, v. 33, suppl. 1, p. 2727-2740, 2012.

VIGNOLO, G. K. et al. Presença de folhas no enraizamento de estacas de amoreira-preta. Ciência Rural, v. 44, n. 3, p. 467-472, 2014.

ZANG, W. et al. Effects of temperature, plant growth regulators and substrates and changes in carbohydrate content during bulblet formation by twinscale propagation in Hippeastrum vittatum 'Red lion'. Scientia Horticulturae, v. 160, n. 1, p. $230-237,2013$. 